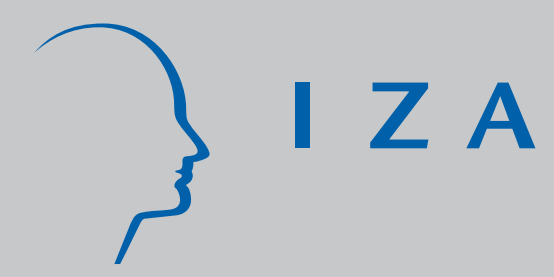

IZA DP No. 1845

Generating Legitimacy for Labor Market and Welfare State Reforms: The Role of Policy Advice in Germany, the Netherlands, and Sweden

Werner Eichhorst

Ole Wintermann

November 2005 


\title{
Generating Legitimacy for Labor Market and Welfare State Reforms: The Role of Policy Advice in Germany, the Netherlands, and Sweden
}

\author{
Werner Eichhorst
}

IZA Bonn

Ole Wintermann

Bertelsmann Foundation

Discussion Paper No. 1845

November 2005

IZA

P.O. Box 7240

53072 Bonn

Germany

Phone: +49-228-3894-0

Fax: +49-228-3894-180

Email: iza@iza.org

Any opinions expressed here are those of the author(s) and not those of the institute. Research disseminated by IZA may include views on policy, but the institute itself takes no institutional policy positions.

The Institute for the Study of Labor (IZA) in Bonn is a local and virtual international research center and a place of communication between science, politics and business. IZA is an independent nonprofit company supported by Deutsche Post World Net. The center is associated with the University of Bonn and offers a stimulating research environment through its research networks, research support, and visitors and doctoral programs. IZA engages in (i) original and internationally competitive research in all fields of labor economics, (ii) development of policy concepts, and (iii) dissemination of research results and concepts to the interested public.

IZA Discussion Papers often represent preliminary work and are circulated to encourage discussion. Citation of such a paper should account for its provisional character. A revised version may be available directly from the author. 
IZA Discussion Paper No. 1845

November 2005

\begin{abstract}
Generating Legitimacy for Labor Market and Welfare State Reforms: The Role of Policy Advice in Germany, the Netherlands, and Sweden ${ }^{*}$

Policy advice can help political actors design and implement institutional reforms through the generation of political and substantial legitimacy. This article clarifies the institutional preconditions of effective supply and transfer of policy advice with particular respect to the field of labor market and social policy reform and to corporatist arrangements where academic think tanks and social partner bodies for policy advice exist side by side. It shows how policy advice is structured and to what it extent it could influence actual policy-making in Germany, the Netherlands, and Sweden over the last decade. Our main argument is that the structure of policy advice is essential for its effectiveness, with highly reputable and less contested expert committees and research institutes providing balanced policy-oriented advice are most influential and conducive to furthering labor market and welfare state reforms in corporatist settings. In combination with a shadow of hierarchy spent by government they can also facilitate social partner consensus. Hence, an appropriate supply of policy advice can help ensure sufficient legitimacy for institutional reforms and increase societal problem-solving capacities. If government is weak for institutional reasons and policy advice rather fragmented, challenged and less policy-oriented, like in the German case, policy advice can not realize its full potential.
\end{abstract}

JEL Classification: H83, J58

Keywords: policy advice, corporatism, labor market reforms, public policy

Corresponding author:

Werner Eichhorst

IZA

P.O. Box 7240

D-53072 Bonn

Germany

Email: eichhorst@iza.org

\footnotetext{
*We are grateful to Eric Seils, Thore Wintermann, and Anton Hemerijck for helpful information on recent developments in policy advice in the Netherlands and Sweden.
} 


\section{Introduction}

Policy advice can help inform policy makers on societal problems, their causes and potential policy solution, thus contributing to appropriate institutional reforms and effective societal problem-solving capacities. The relationship between scientific research and politics, however, is a delicate one, with the effective supply and transfer of policy advice depending on institutional prerequisites in the science sector and the political system so that policy-relevant information is generated and provided so that it can influence the choice and implementation of appropriate policies. This paper first lays out some theoretical considerations on the potential of policy advice with special reference to the area of labor market and welfare state reform, emphasizing the role of policy advice in the generation of legitimacy of often unpopular decisions on reform. We then provide empirical evidence on the role played by policy advice by research institutes, expert committees and other think tanks in social and labor market policy reform in three countries: Germany, the Netherlands, and Sweden. All three are developed welfare states with strong consensus requirements stemming from minority or coalition governments and a strong position of social partners. All faced the need for institutional change, but reacted in different ways. Part of this variation can be explained by the role of policy advice. We therefore analyze the structure of policy advice and its actual function in recent labor market and welfare state reforms. In our analysis we focus particularly on the relationship between 'independent' expertise, social partner bodies and government. The paper shows to what extent the structure of policy advice in Germany inhibits the realization of the full potential of policy advice regarding the design and legitimization of effective policies and why this is different in Sweden and the Netherlands.

\section{The potential of policy advice in labor market and welfare state reform}

Welfare state and labor market reforms aiming at institutions that are consistent with sustainable economic activity and social policies often imply cutbacks on social policy programs, budget consolidation and increased flexibility of the labor market, issues that are in general unpopular and imply distributional effects with short-term losses to be experienced by powerful societal actors and social groups whereas positive effects may take time (Pierson 1994). Therefore, welfare state and labor market reforms are risky and difficult in political terms and can only be adopted and implemented with sufficient legitimacy so that immediate opposition 
and allocation of blame is avoided (Weaver 1986, Pierson 1994). Otherwise, political actors may suffer from loss of political support which is crucial in politics. Status quo orientation of important segments of the electorate stabilizes existing institutions and form barriers to reforms, thus contributing to strong 'path dependence' (Pierson 2000). Science, however, is fundamentally different from politics as it does not deal with acquiring or defending power in electoral campaigns but focuses on the identification of causal relationships between different factors, with economic and social science research into the labor market and the welfare state mainly dealing with the effects of institutions on labor market outcomes, but also with factors conducive to institutional reforms.

In order to analyze the role of policy advice in welfare state and labor market reforms, it is useful to differentiate between the concepts of puzzling and powering (Heclo 1974, Hemerijck/Schludi 2000), puzzling pointing at the process of identifying problems and possible solutions, powering meaning the struggle for political support needed to safeguard the acceptance of reforms. In principle, policy advice can provide valuable input both for the puzzling and the powering phase in policy-making. Regarding puzzling, scientific research can help detect economic or social problems and the main causal factors responsible for them. This, in turn, can help identify potential remedies and effective policy solutions. Policy advice can inform policy-makers about the probable effects of maintaining institutional status quo as opposed to different reform scenarios. Through exploring the preconditions of institutional change, it can also help formulate policy reform strategies. Most effective, however, is political advice if it can be based on a sufficiently broad consensus among experts. A virtual monopoly in policy advice or a unified analytical framework on certain issues may raise the effectiveness of policy advice, but in this case the appropriateness of advice depends crucially upon the control of policy advisors by the scientific community.

With respect to powering, political actors can benefit from policy advice to the extent that is helps legitimizing decisions in political and substantial terms. Political actors can use policy advice in an opportunistic way to justify decisions taken for other reasons with selective reference to experts' statements. But they can also use policy advice to legitimize more farreaching reforms that are painful to major parts of their constituency at least in the short run. Policy advice can be used to bind hands and avert demands to water down reforms and avoid blame, the extent of political and substantial legitimacy to be gained from policy advice also depending upon the extent of consensus among experts. (Dyson 2005). Policy advice can play a crucial role if government faces high consensus requirements, i.e. government formed by coalitions, in situations of minority government or in political systems with social partner 
involvement. In such settings, policy advice can provide potential focal points for compromise and legitimize policy decisions.

Policy advice aiming at relevance with regard to political decisions cannot remain completely 'academic', but has to take both the institutional restrictions of the status quo and the institutional incentives of the political system as well as the politico-economic constellation into account, i.e. the necessity of political actors to gain sufficient political support and legitimization for decisions. The logic of policy-making is not only dominated by the aim of problem solving but also, and maybe to the major part, by the goal of acquiring or defending political power. It may be the case that implementing effective policy raises the chance of political success, but substantial labor market and welfare state reforms are more often controversial and risky in political terms since they imply losses to be experienced by major groups in the electorate with positive effects resulting only in the long run. Therefore, in order to become effective, policy advice has to be organized in a way that facilitates generating policy advice that takes institutional status quo and the political economy of reforms into account. Since this moves beyond the analysis of policies, it may require the creation of a segment of policy advisors either through research institutes specializing in more applied research and policy analysis or temporary or permanent expert committees.

Policy advice may play a specific role in a corporatist setting with strong social partner involvement in formulation and administration of labor market and social policies. Here, institutional infrastructure favoring bi- or tripartite talks can help overcome political deadlock and exploit policy complementarities in particular if institutional settings favor the convergence of policy concepts and broad political exchange (Ebbinghaus/Hassel 2000). But social partner organizations usually also provide policy advice on their own or support think tanks embedded in their respective environment which may neutralize independent policy advice, hamper basic compromise on economic issues and policies and favor joint strategies of externalizing the cost of labor market adjustment. This can be controlled for by a 'shadow of hierarchy' spent by government (Scharpf 1994) or a strong position of non-corporatist policy advice with high reputation in the political sphere, science, and the public.

Therefore, the structure of policy advice will be related to its effectiveness. In the next sections we will analyze the provision of policy advice and assess the role policy advice actually played in recent welfare state and labor market reforms in Germany, the Netherlands, and Sweden. We particularly focus on the relation between the structure of policy advice and the potential for effective influence on the adaptation of social and labor market policies. By do- 
ing so, we aim at empirical evidence of the capacity of policy advice to legitimize reform policies and further societal problem-solving capacities.

\section{Germany: Multiple forms of policy advice, limited effectiveness}

The variety of policy advice in Germany

The German landscape of policy advice in economic and labor market policy is both rich and highly differentiated (Gellner 1995, Thunert 2001, Cassel 2004). We can distinguish several types of providers of policy advice ranging from public research institutes to private and social partners' think tanks and different kinds of corporatist and non-corporatist expert committees.

One group consists of public academic think tanks. This comprises the six leading economic research institutes that receive basic funding from the Federal and the Land Governments in equal shares. The German Institute for Economic Research (DIW, Deutsches Institut für Wirtschaftsforschung) in Berlin, the Munich-based Ifo Institute for Economic Research (ifo Institut für Wirtschaftsforschung), the Centre for European Economic Research in Mannheim (ZEW, Zentrum für Europäische Wirtschaftsforschung), the Rhenish-Westphalian Institute for Economic Research (RWI, Rheinisch-Westfälisches Institut für Wirtschaftsforschung) in Essen, the Kiel Institute for World Economics (IfW, Institut für Weltwirtschaft) and the Halle Institute for Economic Research (IWH, Institut für Wirtschaftsforschung Halle) all cover the whole range of economic research and specialize to a significant part in economic analysis of labor market and social policies. All are evaluated in regular intervals and may lose public funding in case the scientific output is assessed as being insufficient. This happened to the Hamburg Institute of International Economics (HWWA, Hamburgisches Welt-WirtschaftsArchiv) which lost part of the public funding for its research sections after a critical evaluation by the science council and was replaced by the ZEW. HWWA's research activities are now to a significant part taken over by a public/private partnership under the name of Hamburgisches WeltWirtschaftsInstitut (HWWI) whereas HWWA's library will merge with the Kiel Institute's one. The main output of the economic research institutes is the joint economic forecast published on a semi-annual basis in spring and fall each year. Apart from projects funded through research grants from science foundations, they also prepare reports commis- 
sioned by Federal or Land Ministries or other institutions. Since the research institutes rely on stable basic funding they can also carry out autonomous research and provide genuine input to the public debate. Nevertheless, they are clearly part of the academic sector since incentives for scientists working there are set in way that academic achievement is more appreciated than particular effort in policy advice or applied work.

The social sciences feature less prominently in policy advice provided in the area of social and labor market policy. However, there are notable exceptions: the Cologne-based Max Planck Institute for the Study of Societies (MPIfG, Max Planck Institut für Gesellschaftsforschung) and the Social Science Research Center at Berlin (WZB, Wissenschaftszentrum Berlin für Sozialforschung). Although they mainly focus on basic social science research and contributions to the scientific community, both institutes played a major role in policy advice through their directors being members of expert commissions dealing with labor market reform. Wolfgang Streeck, one of the directors of MPIfG, was appointed member of the Benchmarking Committee of the Alliance for Jobs and could thus actively consult the federal government in the late nineties and the early years of this decade. The same was true for Günther Schmid, head of the research unit on labor market policy and employment at WZB, who joined the Benchmarking Committee and also the subsequent Hartz Commission.

Apart from these institutes that are funded through Federal and Land Governments, the Institute Work and Technology (IAT) at Gelsenkirchen specializes in applied labor market and employment research. It depends, however, on resources allocated by the regional government of North Rhine-Westphalia and on research grants whereas the Institute for Employment Research (IAB, Institut für Arbeitsmarkt- und Berufsforschung) in Nuremberg is affiliated with and funded by the Federal Employment Agency, the central body responsible for implementing unemployment insurance and active labor market policy in Germany. It has the legal mandate to carry out research evaluating the effectiveness of labor market policy instruments as well as analyses of regional labor markets. Through this particular position it operates closer to the Federal Ministry of Economics and Labor than other institutes thus benefiting from more direct interaction with policy-makers although tendered research has grown recently so that other research institutes could enter the field of labor market policy evaluation.

Public research institutes are complemented by private institutes. On the one hand, German employers mainly from the metal and electrical industry fund the Cologne Institute for Business Research (IW, Institut der Deutschen Wirtschaft) whereas the Institute of Social and Economic Research (WSI, Wirtschafts- und Sozialwissenschaftliches Institut) is part of the 
Hans Boeckler Foundation, a body funded through trade unions officials' advisory board compensations. Both IW and WSI provide argumentation support for policies favoring their stakeholder and can thus be classified as the social partners' 'advocacy' think tanks. They carry out applied research and publish intensely on subjects highly relevant to their respective communities, thus supporting a certain political tendency in accordance with the general orientation of their principals. In comparison with the publicly funded institutes, both WSI and IW are peculiar in their more intense orientation towards easily accessible publication formats, the media and their stakeholders.

On the other hand, major private enterprises devote part of their wealth and revenue to think tanks organized as or funded by private foundations. The German Post supports the Institute for the Study of Labor (IZA, Forschungsinstitut zur Zukunft der Arbeit), an independent research institute specialized in labor economics and applied labor market research. A different strategy is pursued by the Bertelsmann Foundation, a private think tank organized as an operative enterprise foundation benefiting from part of the profit generated by the Bertelsmann AG, Germany’s largest media company. In contrast to public and private research institutes, the Bertelsmann Foundation is less oriented towards contributing to the scientific debate, but puts more emphasis on the public dissemination of analytical and policy papers and on establishing networks bringing together experts from the academic sphere and policy-makers. The Bertelsmann Foundation aims at furthering reform-oriented action through facilitating the transfer of expertise and policy concepts to actors and the media.

Another major category of policy advisors are permanent expert committees specializing in economic and labor market analysis. The most important one is the German Council of Economic Advisors ("Sachverständigenrat zur Begutachtung der gesamtwirtschaftlichen Entwicklung“) established by legal provisions dating back to 1963. The Council consists of “five wise men”, university professors of economics nominated by the Federal Ministry although an informal rule stipulates that two of them can only be appointed with consent by German employers or trade unions respectively. Nevertheless, the Council has a high reputation for its independent scientific analysis of the German economy and the labor market and for specialized research into selected topics of particular relevance (Wiegard 2005). The main task of the Council is the preparation of an annual report on the German economy and economic policy issues which is published in late autumn. The government is obliged to reply to this analysis through the official Annual Economic Report presented by the Minister of Economics and Labor. Additional scientific advisory councils formed by renowned economists 
exist both at the Ministry of Economics and Labor and the Ministry of Finance and can prepare autonomous reports on selected topics.

Temporary expert committees finally complement the advisory landscape (Siefken 2003). It is useful to distinguish between committees appointed by the government and those created upon initiative by parliament. Regarding labor market policies and reforms the most relevant government-initiated expert commissions were the Benchmarking Committee of the Alliance for Jobs, Vocational Training and Competitiveness (1998-2001) and the Hartz Commission (2002). In a way similar to the Council of Economic Advisors, the first was composed by three independent social scientists, Wolfgang Streeck, the director of the MPIfG, Günther Schmid, the head of the research section on labor markets at the WZB, and Rolf Heinze, a professor from the University of Bochum on the one hand, and the heads of IW, the employers' institute, and the trade unions' Hans Boeckler Foundation on the other. Through this combination of both independent experts and scientists affiliated with the social partners, the Benchmarking Committee was supposed to provide analytic input for the tripartite Alliance for Jobs.

In contrast, the Hartz Commission was a more pluralist expert commission. Peter Hartz, then member of the board of Volkswagen and responsible for personnel affairs, headed a commission created in spring 2002 that was asked to present a reform proposal for labor market policies. The Hartz Commission was formed by fewer scientists, only a minority of representatives from the social partners and some active politicians from the Land and municipal level whereas a more prominent role was reserved for entrepreneurs and business consultants, i.e. professional 'change agents' (Schmid 2003). The model of pluralist expert groups was repeated with the 'Rürup Commission' created in late 2002 in order to formulate reform proposals for the social security system. In contrast to the permanent councils, temporary expert groups have a limited mandate as regards the scope of their task and they are asked to provide not only analysis but also policy recommendations, and their activities end with the presentation of a final report.

Last, but not least, we should not neglect the role played by individual advisors, mainly university professors, members of expert committees or heads of research institutes. Some of them have a high reputation in special fields of expertise and frequently contribute to the public debate via newspaper, radio or television appearances. This is particularly true e.g. for Bert Rürup from the Technical University of Darmstadt, currently head of the German Council of Economic Advisors and spokesman of the Rürup Commission, Karl Lauterbach, a professor 
at the University of Cologne, member of the Rürup Commission and an expert on health policy, Klaus F. Zimmermann, labor economist and head of both IZA and DIW, or Hans-Werner Sinn, president of Ifo institute.

The role of policy advice in German labor market and welfare state reforms

Having outlined the structure of policy advice in Germany, we can analyze the actual role played by policy advisors in recent German labor market and welfare state reforms. First, what is most notable is the relatively minor direct influence exerted by the public research institutes and the permanent expert committees such as the Council of Economic Advisors when it comes to concrete decision-making. Although both the institutes and the Council continuously work on labor market issues and publish their findings regularly, the actual shortterm impact of their analyses and reform proposals is rather limited. Research output, the semi-annual forecasts as well as the Council's annual report receive a certain amount of public attention and are referred to in a selective way by political actors, but they rather provide background information for ministerial officials. A clear short-term influence on actual decisions can hardly be identified although economic research can shape the public debate and agenda in the long run. One reason for this may lie in the fact that neither the analytical nor the conceptual work by the researchers reflects the logic of political decision-making which faces significant institutional and politico-economic restrictions. Hence it is difficult for policy-makers to draft institutional reforms that might be feasible both in political and institutional terms based exclusively on this type of analysis.

Therefore, over the last years the most relevant attempts at labor market reforms were based on the work of temporary expert commissions created explicitly to provide analytical and conceptual input for the government. In comparison to the research institutes and the advisory councils, these commissions adopted a more pragmatic and policy-oriented perspective in that they took political and institutional restrictions into account, thus reflecting the conditions for the realization of their proposals. The most recent commissions also differed in that they did not mainly unite economists but experts with different professional backgrounds. This holds in particular for both the Benchmarking Committee and the Hartz Commission.

As was shown above, the Benchmarking Committee was composed of 'neutral' social scientists and the heads of the research institutions affiliated with the social partners. The aim of the Benchmarking Committee was to establish a set of empirical data on German labor market 
performance as well as on the major institutional factors influencing the former and to assess its strengths and weaknesses so that areas could be identified where reforms were needed most urgently, with policy proposals being derived from 'best practices' in other countries. Through this analytical work, the founders and coordinators of the Alliance for Jobs in the Federal Chancellery expected to reach a joint assessment by trade unions and employers regarding the German employment situation and consensus on potential remedies capable of improving labor market performance. In that way the Alliance for Jobs and the Benchmarking Committee were modeled in accordance with the Dutch model (Visser/Hemerijck 1997, Ebbinghaus/Hassel 2000) which at that time was perceived as an effective regime of cooperative welfare state reform and employment policy in Germany. Building upon futile attempts by the Concerted Action ("Konzertierte Aktion") of the seventies and by the Kohl government in the mid-nineties, the creation of the Alliance for Jobs and the Benchmarking Committee under the Red-Green coalition was an attempt to establish an institutionalized forum for wider and more general discussions between the social partners in Germany and to bring independent researchers and social partner- related institutions together to achieve convergence with regard to assessing the situation and deciding on policy reforms.

However, scientific support of the Alliance for Jobs could not succeed in helping establish a political agenda as both government and social partners were unwilling to engage in a "joint perception of unpleasant facts” and a discussion on substantial reforms (Streeck/Hassel 2003, Siegel 2003). On the one hand this was due to strategic deficiencies and the institutional weakness of the German Federal Government that was neither willing nor capable of inducing employers and trade unions to serious joint reflection and negotiations on labor market reforms within the framework of the Alliance for Jobs. Major concessions to both sides were made by government on an unconditional basis. On the other hand the work of the Benchmarking Committee was hampered by half-hearted support from the social partners' research institutes that also provided counter-evidence supporting their divergent perceptions of German problems. Hence it was not possible to formulate a joint view on the labor market and the institutional adaptations to be implemented as trade unions, employers, and government did not share beliefs concerning the economic situation, its fundamental factors and policy options, the main issue being the diverging perception of the need for institutional adaptations in the welfare state, the role of wage moderation and macroeconomic policies (Dyson 2005).

This was highlighted in the debate on the Committee's proposal to subsidize low-wage earners through reduced social security contributions. Whereas advocates of this approach expected significant job growth favoring the low-skilled, critics from the trade unions feared 
undercutting of established minimum wages, while the employers favored cuts of benefit levels, and government was afraid of the high fiscal cost of such a scheme in the short run (Heinze/Streeck 2003). The final report by the Benchmarking Committee completed in 2001, that provided a comprehensive and comparative assessment of the German labor market (Eichhorst/Profit/Thode 2001), was published at a point in time when the Alliance for Jobs was in severe deadlock and some of the findings advocating institutional adaptation of the German labor market were rejected by the trade unions, whereas the employers claimed part of the arguments to be supportive of their point of view. Hence, it could not form the basis for further joint work by the Alliance for Jobs which was dominated by the social partners' interest in defending established political positions and safeguarding direct access to the government. Faced with persistent deadlock of the Alliance for Jobs, the advisory infrastructure also lost its relevance (Streeck 2003, Streeck/Hassel 2003, Schmid 2003). It is notable, finally, that the analytical work of the Alliance for Jobs was not funded by the government or the social partners but by the private Bertelsmann Foundation, the lack of public funding being a potential sign of the low priority given to this endeavor.

The situation changed completely with the de facto termination of the Alliance for Jobs in early 2002 and the shift to a different temporary expert commission, the Hartz Commission. In direct response to the "placement scandal” in the Federal Employment Agency in early 2002, the Hartz Commission was created upon initiative by the Federal Chancellery and asked to formulate proposals for the reform of labor market policy and administration in Germany (Sell 2005, Schmid 2003). In terms of politics it was the attempt to limit the role of the social partners in German labor market policy which were made responsible for ineffective policy design and implementation. The Federal Employment Agency, one of Germany's largest public administrative bodies, was heavily criticized for its bureaucratic inefficiency which was attributed to a lack of competition and pervasive influence of the social partners advocating ineffective measures favorable to their clientele but detrimental to cost efficiency and the effective operation of labor market policy (Trampusch 2002, Streeck/Trampusch 2005, Sell 2005). Although labor market policies had attracted some criticism in the past, reforming both the administrative setting and the set of instruments was assumed to be virtually impossible and not considered a feasible option before. Most economic policy advisors and the Benchmarking Committee had urged reforms in labor market policy in the past, but this did not enter the political agenda until the placement scandal opened up the window of opportunity for a policy change and a shift in the actor constellation which was a necessary precondition to implement a different labor market policy regime. The reform initiative was triggered by the 
Federal Chancellery, thus marginalizing not only the (then still existing) Ministry of Labor and Social Affairs which was deeply entrenched in corporatist labor market policy controlled by trade unions and employers, but also the established advisory councils, the Alliance for Jobs and the Benchmarking Committee. Through bringing in a pluralist expert group headed by a charismatic labor director of a large firm who had proven his ability to implement innovative models for enterprise-level personnel policy in the past, the work of the Hartz Commission marked a break with past labor market policies and corporatist arrangements. The Hartz Commission, under close supervision by the Chancellery and the media, formulated a package of reform proposals addressing the administration and the set of active labor market policy programs as well as some adjacent policy areas, thus expanding its mandate to cover also employment policy in a broader sense. Reaching consensus among all members of the Commission was not only the personal achievement of Hartz, but also the result of purposeful action neutralizing potential opposition through omitting issues that would have been controversial such as cuts in unemployment benefits or dismissal protection. Consensus was also furthered by package deals, e.g. liberalization of temporary work agencies in exchange for coverage by equal pay or collective agreements. Innovations in terminology and substance stem from the involvement of entrepreneurs and consultants and from policy learning based on the perception of national and foreign 'best practices' (Fleckenstein 2004, Kemmerling/Bruttel 2005, Schmid 2003). Together with the strategic use of the Hartz Commission's work in the Social Democrats' electoral campaign of summer 2002 based on the general statement to fully implement the Hartz reforms in order to halve unemployment over the years to come, the peculiar and ambiguous character of the proposals contributed to the stunning career of the Hartz concept which dominated the political agenda of Chancellor Schröder's second term. In the tight schedule of the run-up to the elections, the government committed itself credibly to a comprehensive implementation of the Hartz proposals, thus attempting to bind hands through "government by commission”, leaving little room for interest group intervention, in particular trade union opposition (Dyson 2005). As with the Benchmarking Committee before, the Bertelsmann Foundation supported the Hartz Commission by providing a collection of 'best practices' of labor market policies at the local level and in other countries and by funding fact-finding missions to some countries (Schmid 2003, Fleckenstein 2004). Finally, the Hartz reforms introduced an innovative element in that the Federal Ministry of Economics and Labor devoted significant resources to careful and comprehensive evaluation, an issue neglected in the past. The main beneficiaries of the evaluation grants are the IAB and the public research institutes, whereas the internal restructuring of the Federal Employment 
Agency was organized with the help of business consultants that had participated in the Hartz Commission.

To take advantage of the reform momentum gained through the Hartz Commission and to further exploit the successful model of a pluralist expert commission as agenda setter for a complex policy area susceptible to deadlock, the government installed the Rürup Commission in autumn 2002. But it was not possible to repeat the Hartz experience. On the one hand, this can be explained by the fact that no window of opportunity was open for a general reconstruction of the pension and health care system. On the other hand the members of the Rürup Commission could not agree on a unified reform proposal on health care funding, the opposing positions having been represented by Rürup and Lauterbach. Finally, interest groups were much more influential in this phase, thus drawing lessons from being taken by surprise by the Hartz Commission and the government's determination to implement the proposals without much debate. The Rürup proposals were also met with stronger resistance from the Social Democratic Party having no pressure to adopt them under the tight schedule of an electoral campaign. The government, however, continued its more active agenda setting through the Agenda 2010, substantially specifying some of the issues raised by Hartz and Rürup (Dyson 2005) which had not been regulated so far, such as reforms in dismissal protection or the determination of the benefit level for the long-term unemployed. This sequence of governmentinitiated reforms was characterized by an erosion of political support and legitimacy that finally resulted in the defeat of the Red-Green coalition in early elections in 2005.

In general, the experience of the Alliance for Jobs, the Hartz and Rürup Commission and the Agenda 2010 show new forms of governance repelling the role of the social partners and their affiliated think tanks and a growing role of temporary expert committees with a pluralistic composition capable of providing pragmatic advice that is of direct use to the policy-making process and helps government-driven agenda setting beyond established party programs. The rise of pluralistic commissions, entrepreneurs and consultants as policy advisors also means that established bodies of scientific expertise such as the Council of Economic Advisors but also the public and the social partners' research institutes are challenged in their position as prominent providers of policy advice and risk losing influence in the political arena as have the party foundations.

In order to counter this threat the Council of Economic Advisors, but also the public research institutes and the think tanks associated with the social partners have modified their publication portfolio and intensified interaction with the public. As regards the Council of Economic 
Advisors, the recent annual reports have become more accessible and more oriented towards concrete reform proposals although, in formal terms, the Council shall not recommend selected policies, e.g. the report issued in autumn 2002 presented a package of labor market reforms. The academic orientation of the public research institutes is now being supplemented by attempts at gaining more attention in the media and the general public through shorter policy papers, workshops with policy makers and more intense media contact.

The need to adapt is even stronger for the social partners' institutes that are affected negatively by, first, the long-term decline of social partnership and organizational membership and, second, the stronger and more autonomous agenda setting by the government. Apart from providing analytical support for their stakeholders, both IW and WSI now increase activities addressing the media and the wider public through short and concise newsletters providing easily accessible information and pointed arguments. Notable is "Chancen für alle”, a medium-term campaign funded by the German metal and electrical industry. Its main activity is the dissemination of information advocating further reforms of the labor market and the welfare state in the direction of a "new social market economy" with a clear liberal orientation, the content for the media mainly being provided by IW. However, the employers' support is camouflaged in that the initiative prefers to appear as independent and non-partisan.

Recent developments of policy advice in Germany show different modes of bridging the wide gap between scientific knowledge and policy-making. This is evident in the growing importance of private think tanks that explicitly adopted a profile different from academic research. Whereas the growing importance of non-academic think tanks and pragmatic advice provided by temporary expert commissions but also business consultants may help overcome the divide between academic research and policy-makers, this may also result in blending highly selective scientific arguments with subtle forms of lobbying in favor of particular economic interests. This may raise some concerns regarding the scientific accuracy and quality of the most influential consulting activities in recent years. It certainly is problematic to cede too much space in political advice to actors that are less transparent and controlled by public discourse or scientific standards. While this might help overcome some of the traditional blockages in German corporatist policy-making and thinking, it might also mean a higher degree of selectivity as regards the "puzzling" phase of policy-making processes with arguments and proposals receiving higher attention if they are orchestrated by more powerful campaigning.

Analyzing policy advice in Germany, we can see that despite of or even due to the wide variety of policy advice and different approaches in recent years the results regarding its effec- 
tiveness are mixed at best. Although legitimizing reforms through policy advice is of particular importance given the precarious resources of German governments, this was only achieved in a particular situation where a window of opportunity could be exploited by government action based on the work of a temporary expert committee like the Hartz Commission. Bypassing the social partners through a pluralist committee was also a clear break with futile attempts at bringing about reforms through corporatist agreements. Despite recent attempts to bridge the gap between science and politics, policy advice still suffers from a strict divide between economics and social science and between academic research and policy-oriented work taking institutional and politico-economic restrictions into account. Hence, policy advice was hardly able to realize its full potential in raising capacities for institutional reform through viable policy proposals and legitimizing further labor market and welfare state reforms. If and why this is different in the Netherlands and Sweden will be shown in the next sections.

\section{The Netherlands: social partnership controlled by independent policy advice}

In the Netherlands, policy advice played a prominent role in labor market and welfare state reform. This is mainly due to specific conditions regarding the supply of policy advice and the discussion of social policy and welfare state issues by social partner bodies (Visser/Hemerijck 1997, Hemerijck 2003, den Butter/Mosch 2003, Andeweg/Irwin 2002).

As regards the science segment, independent but pragmatic and problem-oriented advice has a strong position in the Netherlands. Located right at the heart of policy advice in economic and labor market policy is the Netherlands Bureau for Economic Policy Analysis (CPB, "Centraal Planbureau”) which was established through legislation after the Second World War. Although it is mainly funded by the Ministry of Economic Affairs, it is regarded as an independent policy-oriented research institute. Its major activity is the macro-economic modeling of the Dutch economy and the potential effects of institutional reforms. Due to a long experience in developing and fine-tuning a macroeconomic model of the Dutch economy, it has a virtual monopoly on this kind of analysis. Nevertheless, the CPB's work is up to date with economic research as it interacts intensely with the scientific community. Reputation in science reinforces reputation and credibility in the political sphere which is also strengthened by CPB's mainly empirical approach refraining from direct policy proposals and normative statements. CPB produces the "Central Economic Plan" in spring which forecasts the devel- 
opment of the Dutch economy and some other economies in the current year, which then is updated in autumn's “Macroeconomic Outlook” with a perspective on the following year. This forms the basis for the government's budget proposal presented at the same time. CPB forecasting also influences wage bargaining between the social partners. As CPB's major strength lies in its modeling capacities, it can operate as a sort of "court of audit" ex ante and thus help taking the economic consequences of policy decisions into account, avoid mistakes and strengthen long-term orientation in politics. CPB also evaluates the probable economic and fiscal outcomes of policy proposals that are part of the electoral manifestos presented by political parties. Although referral to the CPB is voluntary, this is high on the public agenda so that political parties cannot refuse to have their proposals evaluated by CPB (Seils 2005). Since all manifestos are assessed using the same macroeconomic model and parties even refer to CPB before formulating their proposals, this leads to convergence in parties' economic policies. CPB also effectively influences coalition negotiations through providing data and simulations of budgetary room to maneuver and an ex ante evaluation of potential policies, this being implemented by the Central Economic Commission of the Ministry of Economics. It helped stabilize budget policy in the Netherlands through the "Zalm norm” of 1994, a limit on real public expenditure that was based on cautious projections by CPB. Apart from forecasting, СРB carries out mandated research and policy analysis for the government and other bodies as regards potential effects of policy proposal, this however in competition with other research institutes, which also means that $\mathrm{CPB}$ has to be competitive and up to date regarding the latest developments in economics. Since CPB maintains strong networks with political actors, ministries, the social partners and other researchers, it can be described as a provider of “commonly understood facts” (Hemerijck 2003).

In addition, the Netherlands Scientific Council for Government Policy (WRR, Wetenschappelijke Raad voor het Regeringsbeleid), which was established by law in 1976, is an important independent and interdisciplinary think tank that is highly influential in raising public and political awareness of long-term issues relevant to the Dutch economy. E.g. in 1990, the WRR presented a report on “A working perspective” (Hemerijck 2003) urging a "paradigm shift” in favor of employment growth and labor market integration instead of lowering open unemployment through reduction of labor supply. By making the inactive/active ratio a major governance benchmark, it facilitated long-term reorientation towards more inclusive and activating labor market policies.

Policy advice in the Netherlands cannot be understood properly without taking social partnership into account. First, the Labor Foundation (STAR, Stichting van de Arbeid), established 
in 1945 under private law and mainly funded through the social partners, operates as a national consultative body. The STAR is formed by the peak associations of employers and trade unions. Within this framework, the social partners can enter pragmatic discussions dealing with a wide range of issues well beyond collective bargaining. They can adopt joint opinions on social or economic subjects and respond to government and parliament requests. The government meets with STAR twice a year. The bipartite Labor Foundation is supplemented by the tripartite Social and Economic Council of the Netherlands (SER, Sociaal-Economische Raad) created by public law in 1950. It is seen as the main advisory body of the Dutch government although it is financed by industry. It brings together employers' peak associations, the peak associations of the Dutch trade unions and a third group of 'crown representatives', i.e. independent experts such as university professors in economics, social science or law, the president of the Dutch Central Bank and the director of CPB. The head of SER is appointed by the government upon proposal by the Council. In the meetings of the Council, but also in the sessions of its tripartite working parties, ministerial officials take part as observers, thus facilitating transfer of information. In SER, the independent members provide input from science and foster compromise. Unanimous statements issued by SER are highly influential with regard to advising the government on economic issues and concrete policy decisions, divided opinions are less effective, but also signal less political support to the government (Hemerijck 2003). As of 1995 mandatory consultation by government was abolished. Incentives to issue unanimous opinions have become stronger within SER since then.

SER and STAR are very much at the heart of the Dutch 'consultation economy'. The corporatist bodies promote exchange and convergence of views on economic problems and possible action to be taken and thus make coordination of policies across policy areas possible. At the same time, social partner bodies rely on analytical work by $\mathrm{CPB}$, which reinforces convergence as regards policy assessment and proposals. This could not be achieved by the Benchmarking Committee in the German Alliance for Jobs. Another important factor that distinguishes the Netherlands from Germany is the stronger role of the government as agenda setter and its potential and sometimes actual threat of intervention (Hemerijck 2003, Seils 2005).

With regard to policy-making, STAR played an important role in reforms in the Netherlands, in particular in the sequence of welfare state and labor reforms triggered by the change in government and the famous Wassenaar agreement in 1982, which was signed at STAR, with both the coalition agreement and the social partners' approach mirroring the analytical findings of CPB (Visser/Hemerijck 1997, Seils 2005). Further steps often relied on joint policy recommendations by the social partners in the 'shadow of hierarchy' and were based on CPB 
work (Hemerijck 2003), such as the agreement “A New Course” in 1993, advocating a more activating labor market policy, and the bipartite agreement on wage restraint in exchange for postponed cuts in disability benefits in 2003, which, after a phase of public unrest, was replaced by a genuine tripartite agreement in 2004, when government backed down on a more stringent reversal of early exit from the labor market (Seils 2005). As regards the administration of social security and labor market policy, the role of social partners was limited after criticism from the crown members of SER, the Dutch Audit Office and an all-party parliamentary enquiry commission, the Buurmeijer commission, which presented its report in 1993, attacking corporatist administration of disability pensions favoring reduction of labor supply. This led to fundamental reorganization of social security and labor market policy administration and further steps at restricting use of disability through the Donner Commission presenting a report in 2001, then, however, supported by SER unanimously. On the other hand, if the social partners can achieve substantial compromise, they can effectively influence legislation as done with the adoption of the 'flexicurity' approach to labor market regulation which was furthered by a STAR document on flexibility and security in 1996 (Hemerijck 2003). The most recent economic difficulties and more intense distributive conflicts in the Netherlands question the effectiveness of the Dutch arrangement of 'smooth' policy advice and policymaking, but it would be premature to claim that it is not operative anymore (Seils 2005, Hemerijck 2003).

Policy advice in the Netherlands is organized through a dense network of researchers, the social partners, and political actors, with the formal setting also allowing for continuous informal exchange of information, analytical findings from different parts of science, but also political arguments, thus helping achieve a high level of trust (den Butter/Mosch 2003). A pragmatic approach towards policy-making is also furthered by the interdisciplinary composition of Dutch labor market research. The Dutch system of policy advice can be seen as an arrangement where CPB and WRR, independent think tanks with high reputation, evaluate policy options and point at long-term challenges, thus improving the governance capacity of the Netherlands. At the same time they control the social partners' STAR and SER, which are effective bodies for policy design and negotiations in that CPB and WRR help limit externalization policies favored by the social partners. Such reforms had to be initiated by the government with analytical support from CPB and WRR since it could not rely on support from the social partners (Hemerijck 2003, Seils 2005). They were rather legitimized with reference to CPB and WRR, but nevertheless Dutch capacity for institutional reform is also enhanced by 
institutional infrastructure for social partners' deliberation in the shadow of hierarchy from the government and based on findings of independent think tanks.

\section{Sweden: Policy advice by institutionalized expert commissions}

Sweden has an institutional arrangement that facilitates the consideration of scientific findings and policy advice in actual policy-making when it comes to welfare state and labor market reforms. Part of the impressive reform sequence in the nineties can partially be attributed to an effective system of policy advice in Sweden (Palme/Wennemo 1998, Benner/Vad 2000, Lindbeck 2002, Jochem 2003, Wintermann 2005).

Two main features play a crucial role: regarding the policy-making process, minority governments have always been quite common in Sweden. A government without a stable majority in parliament, with the prime minister being elected despite the lack of an absolute majority, is more dependent upon sufficient societal support and credible justifications for their decisions. Minority governments have to search for legitimacy for each policy decision. This is a strong incentive for problem-oriented and highly pragmatic policy-making. In such a context policy advice can be helpful in establishing a basis for consensus and in legitimizing deviation from party programs that might be necessary to build an issue-oriented coalition. Therefore, minority governments can be assumed to be more open to policy advice and thus be more able to take long-term considerations arising from advisory bodies into account in order to legitimize their political action.

This relates to the second prerequisite for effective policy advice in Swedish social and employment policy making: the crucial role played by temporary expert committees which differ in their position, their mandates, objectives and operation from advisory councils in other countries (Jann et al. 2005). Expert commissions in Sweden are not primarily involved in the discussion of concrete bills but deal with general and long-term challenges to the Swedish economy and welfare state. The joint opinion of an expert group is expressed in a highly renowned series of reports, the "Statens Offentliga Utredningar" (SOU). These reports shape both public and political debate and also trigger further analysis. Since the public also discusses the findings of SOU reports and is quite aware of the major conclusions, policy-makers are well advised to take the expert commissions' work into account. Upon assignment by the government the Swedish commissions bring members of parliament and experts together; in particular researchers, representatives from the public administration and the social partners 
with some experts having voting rights only. The commissions' work is supported by external experts and assistants; the speaker of a commission is usually not a member of parliament. Regarding the role of academic experts the Swedish commissions benefit from the fact that both experienced and young researchers are involved, the latter having the opportunity to acquire some reputation through their contributions to the commission. The participation of both researchers and members of parliament and the funding through the governments' budget point at the close interaction between scientists and political actors.

Regarding Swedish welfare state reform over the nineties, the SOU played a major role in providing policy orientation and informing political actors on viable policy options. At the beginning of the nineties, commission reports triggered debate on the Swedish welfare state and the need for institutional adaptation (SOU 1990:44, SOU 1994:20, SOU 1996:113, Lindbeck et al. 1994). This is particularly true for preparing the ground for reforms in pensions and invalidity benefits. After initial analysis of demographic changes and their consequences for the economy and the public budget, further commission work resulted in the formulation of a reform proposal for the Swedish old-age pension regime, which was implemented with broad support from the major political parties in 1994 against opposition from the trade unions (Lachman et al. 1995, Palme/Wennemo 1998). The Swedish budgeting procedure was recalibrated after further commission work in 1997 and 2000. In general, we can see that commissions contributed to a rather centralized budgeting and policy-making process involving the social partners much less than in prior phases of corporatist politics in Sweden. In particular, expert commissions helped formulating a strategy to consolidate the public budget and to reform welfare state schemes such as old-age pensions with positive long-term effects on the economy. The Swedish budgeting procedure is now mainly based on the economic framework and forecasting and takes potential effects on the economic activity into account while limiting interest group influence that would have made long-term budget consolidation more difficult (Molander 2001).

Commission work, finally, is supported by research institutes working in the areas examined while at the same time some institutes were even created upon request of a commission. This holds for the CEFOS (Centrum för forskning om offentlig sector) at Gothenburg that specializes in studies on public sector efficiency. Other research institutes are also closely related with the political sphere in that their heads are assigned by the government and the main budgets are allocated by the ministries, among them the Stockholm-based Institute for Future Studies (Institutet för Framtidsstudier) and the Swedish Institute for Social Research (SOFI, Institutet for social forskning) at the University of Stockholm, the major institute for welfare 
state research. In addition, the decentralized National Institute for Working Life (Arbetslivsinstitutet) focuses on working life. The evaluation of active labor market policies and more general labor market research are the main task of the Institute for Labor Market Policy Evaluation (IFAU, Institutet för Arbetsmarknadspolitisk Utvärdering) at Uppsala. Rather skeptical evaluation reports by IFAU influenced the reorientation in Swedish labor market policy in the late nineties away from massive spending and increases in participant inflow in the earlier years of the decade to cuts in expenditure and lower participation (Calmfors/Forslund/Hemström 2001, Jochem 2003). Regarding the steering of scientific research there are research councils dealing with different topics such as the Swedish Council for Working Life and Social Research (FAS, Forskningsråd för arbetsliv och socialvetenskap) that plays an important role in funding social science research in Sweden but also in advising the government.

The essential role of the commission in the long-term adjustment of the Swedish welfare state was emphasized again in the late nineties when the reforms over the last decade were reexamined through commission analyses (SOU 2000:3, 2001:57). Intense public debate, partially fuelled by commission experts participating in series of debates in newspapers such as “Dagens Nyheter” or “Svenska Dagbladet” (Jahn 2003), contributed to high public awareness of underlying problems and viable policy options so that policy makers can hardly ignore the commissions' work. Hence, the commissions' opinions often form focal points for problemoriented solutions beyond party tactics. The high reputation and public standing of the expert commissions helped legitimize this shift which removed budgeting and welfare state reform to a certain degree from party competition and helped adopting a more objective or 'technocratic' approach. It is in that respect similar to the Dutch modeling and forecasting approach. Through these mechanisms - mixed expert commissions including both researchers with different disciplinary backgrounds and political actors; fundamental and balanced reports; and high public awareness -, the findings of the Swedish expert committees have a higher chance of being taken into account in policy-making processes.

The Swedish commissions have proven to be of particular importance with regard to the longterm consolidation of the budget and in promoting structural changes to the welfare state. In recent years they were clearly more important in these policy areas than advice given by the social partners. What is striking in this respect is the erosion of highly centralized Swedish corporatism since the early nineties both regarding social partner influence on the formulation of social and labor market policies, their participation in expert commissions (SOU 1999:121, Jochem 2003), and the transformation of collective bargaining (Wintermann 2005, Jochem 
2003). The most important welfare state reforms were not designed in cooperation with the social partners but mainly pushed by subsequent (often minority) governments in a unilateral way with more emphasis on budget consolidation and structural adjustment facing deep economic crisis in the early nineties and access to the EU when pursuing a national full employment policy was no longer possible. The erosion of corporatist patterns, however, dates back to the mid-seventies when trade unions tried to establish wage earner funds and was highlighted by the breakdown of centralized bargaining caused by the withdrawal of the employers in the early nineties (Meidner/Hedborg 1984, Jahn 1994). Particularly trade unions lost influence as was highlighted in the 1994 pension reform, when they could not influence the political agenda to a significant extent but only postpone the implementation of the new law. However, these reforms paved the way for economic recovery in a fundamentally different economic environment.

Therefore, it seems fair to argue that the institutionalization of the Swedish commissions as an essential part of the policy process both with respect to puzzling and powering helps legitimizing effective policies since a high degree of open and pragmatic public debate provides a high level reputation to the commissions' reports that form the nucleus for generally acceptable policy decisions. The commissions' work also benefits from the existence of a whole range of interdisciplinary research institutes combining economics and social science with a clear empirical and pragmatic approach to societal problems and their potential solution.

\section{Conclusion: Legitimizing welfare state reforms through effective policy advice}

The comparative analysis of policy advice in labor market and welfare state reforms in Germany, the Netherlands and Sweden shows different institutional structures of advisory bodies and divergent experience with the practical relevance of policy advice. As regards Germany, we can see a highly complex arrangement of public and private research institutes, social partner think tanks and both permanent and temporary expert committees. Despite of that there is a deep divide between science and policy makers. However, we can see growing importance of pluralist expert committees with limited mandate and fixed-term duration, the major example being the Hartz Commission which was used to legitimize substantial changes initiated by the government after the breakdown of corporatist concertation. Pluralist expert committees appointed by government seem best to be able to bridge the gap between science and politics and to take institutional and politico-economic restrictions into account, thus gen- 
erating legitimacy for partial welfare state and labor market reforms. However, Germany lacks a structure of policy advice that can generate conceptual convergence, pragmatic compromise and legitimization for reforms compatible with the demands of long-term institutional adjustment. This is different in the Netherlands and Sweden.

The Dutch experience provides a contrasting example as think tanks like CPB and WRR evaluate policies and potential reform options and analyze long-term challenges to the economy and the welfare state whereas social partner institutions provide the institutional infrastructure for close interaction between trade unions, the employers, and the government, thus facilitating convergence. Independent think tanks inform the tripartite talks and point at negative effects of externalization strategies by the social partners. In Sweden, we can see a system that in recent years was no longer characterized by a dominant role of corporatism but by government-induced reforms that could rely on extensive analysis by mixed commissions bringing researchers and policy makers together. Commission reports intensely debated in public can form the basis for policy reforms that are also acceptable to the parliamentary opposition whose consent is often necessary in order to get a majority in parliament. This setting could help legitimize fundamental welfare state reforms in Sweden.

Our analysis shows how the institutional structure of policy advice can help further societal problem-solving capacities with regard to welfare state and labor market reforms. It is fair to say that highly reputable and less contested expert committees and research institutes providing balanced policy-oriented advice are most influential and conducive to furthering labor market and welfare state reforms in corporatist settings. In combination with a shadow of hierarchy spent by government they also facilitate social partner consensus. Hence, an appropriate supply of policy advice can help ensure sufficient political and substantial legitimacy for institutional reforms and increase societal problem-solving capacities. If government is weak for institutional reasons and policy advice is rather fragmented, challenged and less policyoriented, as in the German case, policy advice can not realize its full potential.

\section{References}

Andeweg, Rudy/Irwin, Galen, 2002: Governance and Politics of the Netherlands, New York.

Benner, Mats/Vad, Torben Bungaard, 2000: Sweden and Denmark: Defending the Welfare State. In: Scharpf, Fritz W./Schmidt, Vivien A. (Eds.): Welfare and Work in the Open Economy, Vol. 2, Oxford, pp. 399-466. 
Calmfors, Lars/Forslund, Anders/Hemström, Maria, 2001: Does active labour market policy work? Lessons from the Swedish experiences. In: Swedish Economic Policy Review, 8 (2), 61-131.

Cassel, Susanne, 2004: Politikberatung und Politikerberatung, 2nd ed. Bern.

Den Butter, Frank A.G./Mosch, Robert H.J., 2003: The Dutch miracle: institutions, networks and trust. In: Journal of institutional and theoretical economics, 159 (2), pp. 362-391.

Dyson, Kenneth, 2005: Autoritative and Reflexive Stategies for Binding Hands: Europeanization, Government by Commission, and Economic Reform. In: German Politics, 14 (2), pp. 224-247.

Ebbinghaus, Bernhard/Hassel, Anke, 2000: Striking Deals: The Role of Concertation in the Reform of the Welfare State. In: Journal of European Public Policy, 7 (1), pp. 44-62.

Eichhorst, Werner/Profit, Stefan/Thode, Eric, 2001: Benchmarking Deutschland: Arbeitsmarkt und Beschäftigung, Berlin.

Fleckenstein, Timo, 2004: Policy-Lernen in der Arbeitsmarktpolitik: Das Beispiel der HartzKommission. In: Zeitschrift für Sozialreform, 50 (6), pp. 646-675.

Gellner, Winand, 1995: Ideenagenturen für Politik und Öffentlichkeit, Opladen.

Lachman, Desmond et al., 1995: Challenges to the Swedish Welfare State. IMF Occasional Paper 130, Washington.

Heclo, Hugh, 1974: Modern Social Policy in Britain and Sweden: From Relief to Income Maintenance, New Haven.

Heinze, Rolf G./Streeck, Wolfgang, 2003: Optionen für den Einstieg in den Arbeitsmarkt oder: Ein Lehrstück für einen gescheiterten Politikwechsel. In: Vierteljahrshefte zur Wirtschaftsforschung, 72 (1), pp. 25-35.

Hemerijck, Anton C./Schludi, Martin, 2000: Sequences of Policy Failures and Effective Policy Responses. In: Scharpf, Fritz W./Schmidt, Vivien A. (Eds.): Welfare and Work in the Open Economy, Vol. 1, Oxford, pp. 125-228.

Hemerijck, Anton C., 2003: A Paradoxical Miracle: the Politics of Coalition Government and Social Concertation in Dutch Welfare Reform. In: Jochem, Sven/Siegel, Nico A. (Eds.): Konzertierung, Verhandlungsdemokratie und Reformpolitik im Wohlfahrtsstaat - Das Modell Deutschland im Vergleich, Opladen, pp. 232-270.

Jahn, Detlef, 1994: Das Schwedische Modell - Zukunfts- oder Auslaufmodell?, in: Rising Hintz, Gunilla (Ed.), Das Schwedische Modell - Zukunfts- oder Auslaufmodell?, DeutschSchwedische Gespräche, Marburg, pp. 21-38.

Jahn, Detlef, 2003: Das politische System Schwedens. In: Ismayr, Wolfgang (Ed.): Die politischen Systeme Westeuropas, 3rd ed., Opladen, pp. 93-130.

Jann, Werner, 1989: Parlament und Gesetzgebung: Aketure und Ressourcen der parlamentarischen Gesetzgebung im internationalen Vergleich, Habilitationsschrift, Hochschule für Verwaltungswissenschaft, Speyer.

Jann, Werner et al., 2005: Regierungsorganisation als Institutionenpolitik: Ein westeuropäischer Vergleich, Forschungspapiere „Regierungsorganisation in Westeuropa“ 01/2005, Potsdam.

Jann, Werner/Tiessen, Jan, 2005: Gesetzgebung in Schweden, mimeo, Berlin. 
Jochem, Sven, 2003: Das schwedische Modell im Wandel. In: Jochem, Sven/Siegel, Nico A. (Eds.): Konzertierung, Verhandlungsdemokratie und Reformpolitik im Wohlfahrtsstaat Das Modell Deutschland im Vergleich, Opladen, pp. 271-310.

Kemmerling, Achim/Bruttel, Oliver, 2005: New Politics in German Labour Market Policy? The Implications of the Recent Hartz Reforms for the German Welfare State, WZB Discussion Paper SP I 2005-101, Berlin.

Lindbeck, Assar, 2002: Changing Tides for the Welfare State, CESifo working Paper 645 (3), Munich.

Lindbeck, Assar et al., 1994: Turning Sweden Around, Cambridge, Mass.

Meidner, Rehn/Hedborg, Anna, 1984: Modell Schweden - Erfahrungen einer Wohlfahrtsgesellschaft, Frankfurt.

Molander, Per, 2001: Budgeting Procedures and Democratic Ideals. In: Journal of Public Policy, 21 (1), pp. 23-52.

Palme, Joakim/Wennemo, Irene, 1998: Swedish Social Security in the 1990s: Reform and Retrenchment, Välfärdsprojektet, Printing Works of the Cabinet Office and Ministries, Stockholm.

Pierson, Paul, 1994: Dismantling the Welfare State? Reagan, Thatcher, and the Politics of Retrenchment, Cambridge.

Pierson, Paul, 2000: Increasing returns, path dependence, and the study of politics. In: American Political Science Review, 94 (2), pp. 251-267.

Scharpf, Fritz W., 1994: Games real actors could play. In: Journal of Theoretical Politics, 6 (1), pp. 27-53.

Schmid, Günther, 2003: Gestaltung des Wandels durch wissenschaftliche Beratung. Das ,Bündnis für Arbeit' und die ,Hartz-Kommission'. In: Ramge, Stefan/Schmid, Günther (Eds.): Management of Change in der Politik? Reformstrategien am Bespiel der Arbeitsmarkt- und Beschäftigungspolitik. Münster, pp. 68-86.

Seils, Eric, 2005: Das Holländische Wunder: Korporatismus und Konsens oder konfliktgeladene haushalts- und finanzpolitische Anpassung? In: Zeitschrift für Sozialreform, 51 (2), pp. 194-220.

Sell, Stefan, 2005: Vom Vermittlungsskandal der Bundesanstalt für Arbeit zu Hartz IV: Tiefen und Untiefen rot-grüner Arbeitsmarktpolitik in einer Mediengesellschaft. In: Haubner, Dominik/Mezger, Erika/Schwengel, Hermann (Eds.): Agendasetting und Reformpolitik. Strategische Kommunikation zwischen verschiedenen politischen Welten. Marburg, pp. 285-310.

Siefken, Sven T., 2003: Expertengremien der Bundesregierung - Fakten, Fiktionen, Forschungsbedarf. In: Zeitschrift für Parlamentsfragen, 34 (3), pp. 483-504.

Siegel, Nico A., 2003: Die politische Ökonomie der Konzertierung in Deutschland. Das Beispiel Bündnis für Arbeit. In: Jochem, Sven/Siegel, Nico A. (Eds.): Konzertierung, Verhandlungsdemokratie und Reformpolitik im Wohlfahrtsstaat. Das Modell Deutschland im Vergleich, Opladen, pp. 148-193.

Statens offentliga utredningar, 1990: Makt och demokrati, SOU 1990:40, Stockholm.

Statens offentliga utredningar, 1994: Reformerat pensionssystem - Betänkande av Pensionsarbetsgruppen, SOU 1994:20, Stockholm. 
Statens offentliga utredningar, 1996: En allmän och aktiv försäkring vid sjukdom och rehabilitering, SOU 1996:113, Stockholm.

Statens offentliga utredningar, 1999: Avkorporativisering och lobbyism, SOU 1999:121, Stockholm.

Statens offentliga utredningar, 2000: Välfärd vid vägskäl, SOU 2000:3, Stockholm.

Statens offentliga utredningar, 2001: Välfärdens finansering och fördelning, SOU 2001:57, Stockholm.

Streeck, Wolfgang, 2003: No longer the Century of Corporatism. Das Ende des "Bündnisses für Arbeit”, MPIfG Working Paper 03/4, Köln.

Streeck, Wolfgang/Hassel, Anke, 2003: The Crumbling Pillars of Social Partnership. In: West European Politics, 26 (4), pp. 101-124.

Streeck, Wolfgang/Trampusch, Christine, 2005: Economic Reform and the Political Economy of the German Welfare State. In: German Politics, 14 (2), pp. 174-195.

Thunert, Martin, 2001: Politikberatung in der Bundesrepublik Deutschland seit 1949, in: Willems, Ulrich (Ed.): Demokratie und Politik in der Bundesrepublik, Opladen, pp. 223-242.

Trampusch, Christine, 2002: Die Bundesanstalt für Arbeit und das Zusammenwirken von Staat und Verbänden in der Arbeitsmarktpolitik von 1952 bis 2001. MPIfG Working Paper 02/5, May 2002.

Visser, Jelle/Hemerijck, Anton, 1997: ,A Dutch Miracle’. Job Growth, Welfare Reform and Corporatism in the Netherlands, Amsterdam.

Weaver, R. Kent, 1986: The Politics of Blame Avoidance. In: Journal of Public Policy, 6 (4), pp. 371-398.

Wintermann, Ole, 2005: Vom Retrenchment zur Krisenreaktionsfähigkeit - Ein empirischer Vergleich der Wohlfahrtsstaaten Schweden und Deutschland 1990-2000, Wiesbaden.

Wiegard, Wolfgang, 2005: Politikberatung im internationalen Vergleich, in: Schäfer, Wolf/Giersch, Herbert (Eds.): Institutionelle Grundlagen effizienter Wirtschaftspolitik, Berlin, pp. 83-92.

Zimmermann, Klaus F., 2004: Advising Policy-Makers Through the Media. In: Journal of Economic Education, 35 (4) 2004, pp. 395-405. 